\title{
COL1A1 wt Allele
}

National Cancer Institute

\section{Source}

National Cancer Institute. COL1A1 wt Allele. NCI Thesaurus. Code C52453.

Human COL1A1 wild-type allele is located in the vicinity of $17 q 21.33$ and is approximately $18 \mathrm{~kb}$ in length. This allele, which encodes collagen alpha-1 (I) chain protein, is involved in both the development and maintenance of tendon, ligaments and bones. Mutations in the gene are associated with both Ehlers-Danlos syndrome and osteogenesis imperfecta types. In cases of dermatofibrosarcoma protuberans the gene is involved in a translocation $\mathrm{t}(17 ; 22)(\mathrm{q} 22 ; \mathrm{q13})$ with the PDGF gene. 